\title{
The Influence of Protein Content and Some Hydrocolloids on Textural Attributes of Spreadable Processed Cheese
}

\section{Nassra Dabour and Ali EL-Shanshory}

Functional Foods and Nutraceuticals Laboratory (FFNL), Department of Dairy Science and Technology, Faculty of Agriculture, University of Alexandria, Alexandria, Egypt.

Corresponding Author: Nassra Dabour, University of Alexandria, Department of Dairy Science and Technology, Faculty of Agriculture, Box 21545, Alexandria, Egypt.

E-mail:nassradabourr@ymail.com

Received date: 23 May 2018, Accepted date: 22 August 2018, Online date: 4 September 2018

Copyright: (c) 2018 Nassra Dabour and Ali EL-Shanshory. This is an open-access article distributed under the terms of the Creative Commons Attribution License, which permits unrestricted use, distribution, and reproduction in any medium, provided the original author and source are credited.

\begin{abstract}
Background: There is growing interest to incorporate hydrocolloids in the production of reduced-fat processed cheese and cheese analogue where they can act as fat replacers and as water binder. Also there is growing demand to replace traditional emulsifying salts, either partially or completely, by hydrocolloids in processed cheese production. As the emulsifying salts contain high amount of phosphorus and sodium which represent health concern for processed cheese consumers. Thus in the present study we aimed to integrate some hydrocolloids in the production of processed cheese analogue including, native starch, modified starch, carrageenan, guar gum, carboxymethyl cellulose, xanthan gum and two commercial stabilizing mixtures known as Hitex 555 and Dairy gel 161. Objectives: The present study was undertaken to evaluate 1) the effect of protein concentration on textural characteristics of spreadable processed cheese analogue, 2) the effect of some textural stabilizing agents on textural attributes of spreadable processed cheese analogue containing $6 \%$ protein, and 3) develop stabilizer mixture(s), based on the performance of individual stabilizers, to be used in stabilizing texture of spreadable processed cheese analogue. Results: Textural measurements indicated that the values for hardness, cohesiveness, gumminess and chewiness decreased significantly as protein content of cheese decreased. Adhesiveness and springiness values decreased slightly or remained relatively constant as protein concentration reduced from 12 to $8 \%$ while cheese containing $6 \%$ protein had significantly the highest values for such textural parameters. Cheeses made with different hydrocolloids had similar chemical composition and microbiological quality. The incorporation of hydrocolloids in cheese blends resulted in cheeses with different textural attributes depended on type of hydrocolloid added. Based on the textural profile generated by different stabilizers, two stabilizer mixtures were developed and identified as Car mixture (native starch: modified starch: carrageenan at ratio 85.7: 10.7: 3.6) and Xan mixture (native starch: modified starch: xanthan at ratio 85.7: 10.7: 3.6). These mixtures were further incorporated into cheese blends to evaluate their impact on textural attributes during 6 month of storage of spreadable cheese at ambient temperature. Results revealed that none of developed mixture had adverse effect on chemical composition, microbiological quality and sensorial attributes of spreadable cheeses. Cheeses containing either Car or Xan mixture had significantly lower values for hardness, cohesiveness, springiness, gumminess and chewiness compared with control cheese. During storage, all cheeses showed the same tendency in which values for hardness, cohesiveness, springiness, gumminess and chewiness decreased significantly $(\mathrm{P} \leq$ 0.05 ) as storage period progressed. Conclusion: Results indicate that both stabilizer mixtures developed in this study could be recommended to be used in the production of spreadable processed cheese analogue as they had no adverse effects on chemical, microbiological, textural and sensorial attributes of cheese.
\end{abstract}

Key words: Stabilizers, processed cheese, cheese analogue, textural attributes

\section{INTRODUCTION}

Processed cheese is one of the most popular dairy products worldwide particularly for children and pregnant woman. Processed cheese is a dairy product that made by cocking (heating combined with mixing) of ingredients including natural cheeses, emulsifying salts and other dairy or non-dairy ingredients. It has a long history dating back to the early part of the $20^{\text {th }}$ century. Processed cheese has considerable economic importance due to their suitability for storage, transportation, home use as well as for snack restaurants. There are three main forms of processed cheeses, blocks, spreads or slices.

Indeed, there is continuous increase in production and consumption of processed cheese worldwide. In Egypt, production and consumption of processed cheese has increased steadily during the last two decades. Processed cheese industry is considered to be the fasts growing dairy sector in Egypt and represents approximately 20-25\% of Egyptian cheese market. Also exportation of Egyptian processed cheese increased steadily and gradually during the last two decades. According to FAO statistics (2011), Egypt exported approximately 180 tons of processed cheese in 2005 which increased in year 2011 to 62,282 tons [1]. The annual consumption of Egyptian people of processed cheese also increased gradually and was estimated to be $2.46 \mathrm{~kg} / \mathrm{capita}$ in year 2010 [2].

Processed cheese varieties are usually distinguished by texture - comprising a broad range from firm usually distributed in blocks, slices or in grated form, to creamy processed cheese spreads - and also by composition. In addition, processed cheese analogue is another group of processed cheese which is usually made of blends containing vegetable fat and casein. Cheese analogue has been developed as need and necessity to produce cheaper and healthier product. This urges manufacturers to seek vegetable ingredients to replace milk fat or proteins, either partially or completely, in processed cheese blends. 
Citation: Nassra Dabour and Ali EL-Shanshory, 2018. The Influence of Protein Content and Some Hydrocolloids on Textural Attributes of Spreadable Processed Cheese. Journal of Applied Sciences Research., 14(5): 5-11. DOI: 10.22587/jasr.2018.14.5.2

The main ingredients used in processed cheese formulation are natural cheeses, butter, protein powders, salt, water, emulsifying salts and stabilizers or hydrocolloids. Among ingredients emulsifiers are considered the most revolutionary component used in processed cheese manufacture which improves its quality, functionality and marketability [3]. Emulsifiers are important ingredient as they may account for 3.5\% of the total composition of processed cheese blend. For cheese functionality, emulsifying salts have been reported to improve cheese meltability, flowability, and stretchability and reduce oil separation [4]. In addition, emulsifying salts can affect the hydration of the protein of cheese. The hydrated protein can then emulsify the fat released due to heating and mixing procedures carried out during processing [5]. The principal emulsifying salts used in processed cheesed formulation are sodium phosphates, especially sodium orthophosphates, and sodium citrates, especially trisodium citrate [6].

Although phosphorus and sodium are essential nutrient the excessive consumption of such element may adversely affect health. High levels of dietary phosphorus and sodium have been linked to some health risks. High consumption of phosphorus is linked to osteoporosis [7], while excessive amounts of sodium were considered predisposing factor of cardiovascular and hypertension [8 and 9].

Nowadays, there is growing demands to reduce the amount of phosphorus and sodium in food. Research has been initiated two decades ago to replace traditional emulsifying salts, either partially or completely, by hydrocolloids in processed cheese production. Hydrocolloids (polysaccharide- or protein-based) are helpful to form stable gels and to create and disperse emulsions [10]. Polysaccharide-based hydrocolloids such as natural and modified starches, carrageenan, pectin, xanthan and locust bean gum are extensively used in food formulation. Gelatine, casein, caseinates and whey proteins are the most common protein-based hydrocolloids used for stabilizing food texture [11and 12]. Indeed, hydrocolloids are generally considered to be stabilizers of emulsions rather than true emulsifiers. The replacement of emulsifying salts by hydrocolloids in processed cheese blends would have many advantages including (i) reduction of cost production (ii) reduction of the concentration of phosphorus and sodium in processed cheese and (iii) establishment of new healthier processed cheese [10]. In this context, the present study aimed to 1) evaluate the effect of protein concentration and some textural stabilizing agents (starch, modified starch, carrageenan, guar gum, carboxymethyl cellulose and xanthan gum, in addition to 2 commercial food stabilizing agents known as Hitex 555 and Dairy gel 161) on textural attributes of spreadable processed cheese analogue and 2) develop stabilizer mixtures to be used in stabilizing texture of spreadable processed cheese analogue.

\section{1-Materials:}

\section{MATERIALS AND METHODS}

Skim milk powder (33.4\% protein and 3.8\% moisture) was imported from Dairy milk Inc., Cdi Fresno, California, USA. Cheddar cheese (36.2\% fat and $64.3 \%$ total solids) was obtained from Fonterra Inc., Auckland, New Zealand. Shortening (non hydrogenated palm oil) was obtained from IFFCO (Suez city, Egypt). The emulsifying mixture JOHA-S4 consisted of poly and diphosphates was obtained from BK Giulini CMBH, Ladenburg, Germany. Iodized refined edible fine table salt was obtained from Egyptian Salt and Minerals Company, Alexandria Egypt. Potassium sorbate was obtained from Ningbo Wanglong Technology Co., Ltd, Zhejiang, China. Commercial vegetable protein (Egy protein2) composed of $4.5 \%$ protein and $88.5 \%$ carbohydrates was obtained from The Egyptian Company for Dairy Products and Food Additives "Egy- Dairy" $10^{\text {th }}$ of Ramadan city, Egypt. Maize native starch was obtained from the National Company for Maize Products at $10^{\text {th }}$ of Ramadan city, Egypt. Modified maize starch was obtained from Roquette Laisa, Espana, S.A. Valencia, Spain. Xanthan, carrageennan, Guar Gum, Carboxymethyl cellulose, nisin and citric acid were purchased from AWA Company, Borg Al Arab, Alexandria, Egypt. Commercial food stabilizer mixture known as "Dairy gel 161" is composed of modified starch, mono and diglycerides, carboxymethyl cellulose, guar gum and bovine gelatin. Dairy gel 161 was obtained from The Egyptian Company for dairy products and Food Additives "Egy- Dairy" $10^{\text {th }}$ of Ramadan city, Egypt. Hitex 555 was obtained from Zahran Co., Alexandria, Egypt.

\section{2- Preparation of spreadable processed cheese analogue:}

The composition of different spreadable processed cheeses made in this study was shown in Table 1. To evaluate the effect of protein concentration on textural attributes of spreadable processed cheeses analogues, four blends with 12, 10, 8 and 6\% protein were formulated and coded as P1, P2, P3 and P4, respectively. To evaluate the effect of different stabilizers (including native starch, modified starch, carrageenan, guar gum, carboxymethyl cellulose, xanthan gum, Hitex 555 and Dairy gel 161) on textural properties of spreadable processed cheese, eight blends were formulated to contain $6 \%$ protein and coded as S1 to S8. Based on rheological behaviour of each to evaluate the effect of textural stabilizing agents on cheese spreads containing $6 \%$ protein, 2 stabilizer mixtures were developed and coded as Car and Xan mixtures. They mainly composed of native starch: modified starch: carrageenan or xanthan at ratio of 85.7: 10.7: 3.6, respectively. The impact of both mixtures on changes of textural attributes during storage of spreadable cheese was evaluated through the formulation of 2 cheese blends containing $6 \%$ protein coded as Car and Xan (Table 1). Stabilizer-free cheese blend (P1) containing 12\% protein was produced and served as control.

Blends were prepared and manufactured at Faragalla Company (Borg Al-Arab, Alexandria, Egypt) using a $90 \mathrm{~kg}$ capacity batch cooker Uzermak (Yazibasi Beldesi Bahcelievler Mah. Sakarya Cad. No:18 TORBALI-IZMIR, Turkiye, Turkey). Processing was carried out at a temperature of $90^{\circ} \mathrm{C}$ for 4 min as previously described [13]. Processed cheese was packed using Corraza FF220v machine Sympak Corazza (Bologna-Italy).

A blend of $60 \mathrm{~kg}$ was prepared for each cheese trial and the amount of ingredients was calculated in order to fulfill the Egyptian standard specification for full-fat spreadable processed cheese analogue [14]. According to the Egyptian standards, spreadable processed cheese should contain 35-65\% fat/dry matter and $36 \%$ dry matter.

Following production, cheeses made with different levels of protein (P1 to P4) and those with different stabilizers (S1 to S8) were kept at ambient temperature $\left(25 \pm 2^{\circ} \mathrm{C}\right)$ for $24 \mathrm{~h}$ prior to be subjected to textural measurements. Cheeses made with stabilizer mixtures Car and Xan in addition to stabilizer free cheese were stored at ambient temperature $\left(25 \pm 2^{\circ} \mathrm{C}\right)$ for 6 months. Samples were taken at 60 days intervals for chemical, microbiological, textural and sensorial assessments.

\section{Cheese analyses:}

3.1. Chemical analysis:

Dry matter content of processed cheese was determined according to AOAC method [15]. A sample of approximately $3 \mathrm{~g}$ was weighed precisely and dried for 3 to $4 \mathrm{hrs}$ at $105 \pm 2^{\circ} \mathrm{C}$ until a constant weight was obtained. Fat was determined using special Gerber tube designed for fat determination in cheese [15]. Total protein was determined according to the method described by International Dairy Federation_using Kjeldahl Semi-automized Foss model 8100 Dairy Analyzer (FOSS analytical, Hilleroed, Denmark) [16]. Salt content was determined using a corning chloride analyzer 926 (Crison instrument, Spain) [15]. The pH value was measured using $\mathrm{pH}$ meter (Crison instrument, Spain).

\subsection{Microbiological analysis:}

The total viable bacterial count was enumerated on plate count agar medium at $32^{\circ} \mathrm{C}$ after $48 \mathrm{~h}$ [17]. Coliform bacteria were enumerated on violet red bile agar medium for enumerating of coliform at $37^{\circ} \mathrm{C}$ for $24 \mathrm{~h} \mathrm{[17].} \mathrm{Counts} \mathrm{of} \mathrm{aerobic} \mathrm{spore} \mathrm{forming} \mathrm{bacteria} \mathrm{were} \mathrm{determined} \mathrm{on} \mathrm{nutrient} \mathrm{agar} \mathrm{medium} \mathrm{at} 37^{\circ} \mathrm{C}$ according to [18]. Anaerobic spore forming bacteria were enumerated on reinforced clostridial agar and incubated anaerobically in Oxoid jars using an atmosphere generation system (Oxoid AnaeroGenTM; Oxoid Ltd, Basingstoke, Hampshire, UK) at $37^{\circ} \mathrm{C}$ for $48 \mathrm{~h}$. Molds and yeasts were enumerated on potato dextrose agar medium and plates were incubated at $25 \pm 2^{\circ} \mathrm{C}$ for 5 days [19].

\subsection{Texture profile analysis (TPA):}

Texture properties of cheese were evaluated using a texture analyser (TA1000, Lab Pro (FTC TMS-Pro), USA). Double compression test was performed and operated at a crosshead speed $50 \mathrm{~mm} / \mathrm{sec}$ using 45 degree cone Perspex.

The following parameters were evaluated according to the definitions given by the International Dairy Federation (1991) [20]:

Hardness (g): the force required to produce a given deformation;

Adhesiveness $(\mathrm{g} / \mathrm{mm})$ : the work needed to overcome attractive force between food and other surfaces,

Cohesiveness (no dimension): the quantity to simulate the strength of the internal bonds making up the body of the product,

Springiness or elasticity $(\mathrm{mm})$ : the rate at which a deformed material goes back to its undeformed condition after the deforming force is removed, 
Citation: Nassra Dabour and Ali EL-Shanshory, 2018. The Influence of Protein Content and Some Hydrocolloids on Textural Attributes of Spreadable Processed Cheese. Journal of Applied Sciences Research., 14(5): 5-11. DOI: 10.22587/jasr.2018.14.5.2

Gumminess (g): the quantity to simulate the energy required to disintegrate a semi-solid food product to a state ready to swallowing, (Gumminess= hardness $\mathrm{x}$ cohesiveness) and

Chewiness (g): the quantity to simulate the energy required to masticate a solid food product to a state ready for swallowing, (chewiness= gumminess $\mathrm{x}$ springiness).

\subsection{Sensory evaluation}

Cheese samples coded P1, Car and Xan were subjected to sensorial evaluation after $24 \mathrm{~h}$ following production (fresh cheese) and after 2, 4 and 6 months of storage at ambient temperature $\left(25 \pm 2^{\circ} \mathrm{C}\right)$. Five sensorial attributes including, colour, odour, taste, consistency and oiling off were evaluated using a hedonic scale from 1 to 10 [21]. Cheeses were assessed by a score panel of 12 experienced personnel belong to the staff members of Dairy Science and Technology Department, Faculty of Agriculture, Alexandria University and Faragalla Group Company for Food products (Bourg El-Arab city, Alexandria).

\subsection{Statistical analysis:}

In experimental sets dealt with the effect of protein concentration and type of stabilizers analyses were carried out after $24 \mathrm{~h}$ following production (fresh cheese). Experimental set aimed to evaluate the effect of stabilizer mixtures on changes in chemical, microbiological and textural attributes during storage of spreadable cheese, analyses were undertaken when cheese was fresh and after 2, 4 and 6 months of storage.

Cheese were sampled in duplicate for each analysis and analysed twice. Data shown in this study were mean values \pm standard deviations. F-test and analysis of variance of treatments difference were performed as described previously [22]. Statistical analysis was done by ANOVA, F-test and least significant difference (L.S.D) procedures available within the SAS software package (version 9.13, 2007). Differences between treatments with $P \leq 0.05$ were considered to be statistically significant.

Table 1: Formulation of different spreadable processed cheeses manufactured in this study.

\begin{tabular}{|c|c|c|c|c|c|c|c|c|c|c|c|c|c|c|}
\hline \multirow[t]{3}{*}{ Ingredients (kg) } & \multicolumn{14}{|c|}{ Code of experimental cheeses } \\
\hline & \multicolumn{4}{|c|}{$\begin{array}{l}\text { Cheeses made with different } \\
\text { protein concentration }{ }^{* 1}\end{array}$} & \multicolumn{8}{|c|}{ Cheeses made with different stabilizers ${ }^{* 2}$} & \multicolumn{2}{|c|}{$\begin{array}{l}\text { Cheeses made } \\
\text { with stabilizer } \\
\text { mixtures }^{* 3}\end{array}$} \\
\hline & P1 & $\mathbf{P 2}$ & P3 & $\mathbf{P 4}$ & S1 & S2 & S3 & S4 & S5 & S6 & S7 & S8 & Car & Xan \\
\hline Cheddar cheese & 19.5 & 13.5 & 9 & 4 & 4.0 & 4.0 & 4.0 & 4.0 & 4.0 & 4.0 & 4.0 & 4.0 & 4.0 & 4.0 \\
\hline skim milk powder & 7.4 & 7.9 & 7.6 & 7.5 & 7.5 & 7.5 & 7.5 & 7.5 & 7.5 & 7.5 & 7.5 & 7.5 & 7.5 & 7.5 \\
\hline Shortening & 7.8 & 9.9 & 11.6 & 12.4 & 12.4 & 12.4 & 12.4 & 12.4 & 12.4 & 12.4 & 12.4 & 12.4 & 12.4 & 12.4 \\
\hline Emulsifying salt S4 & 1.5 & 1.5 & 1.5 & 1.5 & 1.5 & 1.5 & 1.5 & 1.5 & 1.5 & 1.5 & 1.5 & 1.5 & 1.5 & 1.5 \\
\hline Egy protein 2 & 0.0 & 1.5 & 3.0 & 3.8 & 0.8 & 2.6 & 3.62 & 3.5 & 3.5 & 3.5 & 3.2 & 3.5 & 1.00 & 1.00 \\
\hline Salt & 0.15 & 0.15 & 0.15 & 0.25 & 0.25 & 0.25 & 0.25 & 0.25 & 0.25 & 0.25 & 0.25 & 0.25 & 0.25 & 0.25 \\
\hline Potassium sorbet & 0.06 & 0.06 & 0.06 & 0.06 & 0.06 & 0.06 & 0.06 & 0.06 & 0.06 & 0.06 & 0.06 & 0.06 & 0.06 & 0.06 \\
\hline Nisin & 0.01 & 0.01 & 0.01 & 0.01 & 0.01 & 0.01 & 0.01 & 0.01 & 0.01 & 0.01 & 0.01 & 0.01 & 0.01 & 0.01 \\
\hline Citric acid & 0.15 & 0.15 & 0.15 & 0.15 & 0.15 & 0.15 & 0.15 & 0.15 & 0.15 & 0.15 & 0.15 & 0.15 & 0.15 & 0.15 \\
\hline Stabilizer mixture & 0.0 & 0.0 & 0.0 & 0.0 & 3.0 & 1.2 & 0.18 & 0.30 & 0.30 & 0.30 & 0.60 & 0.30 & 2.80 & 2.80 \\
\hline Water & 23.5 & 25.4 & 27.0 & 30.3 & 30.3 & 30.3 & 30.3 & 30.3 & 30.3 & 30.3 & 30.3 & 30.3 & 30.3 & 30.3 \\
\hline Total $(\mathrm{kg})$ & 60 & 60 & 60 & 60 & 60 & 60 & 60 & 60 & 60 & 60 & 60 & 60 & 60 & 60 \\
\hline
\end{tabular}

${ }_{* 2}^{* 1}$ Cheeses made with different protein concentration (12, 10, 8 and 6\%) were coded as P1, P2, P3 and P4, respectively.

${ }^{{ }^{*}}$ Cheeses containing $6 \%$ protein made with different stabilizers including native starch (S1), modified starch (S2), carrageenan (S3), guar gum (S4), carboxymethyl cellulose (S5), xanthan gum (S6), Hitex 555 (S7) and Dairy gel 161 (S8), respectively.

${ }^{*}$ Cheeses containing 6\% protein made with stabilizer mixtures Car: cheese made with stabilizer mixture composed of starch: modified starch and carrageenan (85.7, 10.7 and 3.6, respectively), Xan: cheese made with stabilizer mixture composed of starch: modified starch and xanthan gum (85.7, 10.7 and 3.6, respectively).

\section{RESULTS AND DISCUSSION}

Effect of protein content on textural properties of spreadable processed cheeses:

Textual measurements of cheeses made with different levels of protein are shown in Table (2). In general, values for hardness, cohesiveness, gumminess and chewiness decreased $(P \leq 0.05)$ as protein content of cheese decreased. However, adhesiveness and springiness appeared to be less affected by the reduction of protein level in cheese. The reduction of protein level in cheese to $8 \%$ had slight effect on values for such rheological parameter while cheese containing $6 \%$ protein (P4 cheese) exhibited the highest values for both measurements.

It has been reported that the chemical composition (e.g., fat, water and protein contents and type and amount of emulsifying salts etc....) and processing conditions (temperature, stirring speed, cooling rate and processing time) determine to far extent the textural characteristics of a processed cheese [23, 24 and 25]. For example, values for hardness, cohesiveness and springiness have been shown to correlate proportionally with milk solid not fat and fat/dry matter contents [26]. The protein content of a processed cheese has been shown to have significant impact on its own texture. The reduction in protein content, as in P2 to P4 cheeses, of processed cheese led to the formation of cheese with low firmness values [27, 28 and 29]. Consequently, values of firmness-derived textural parameters (e.g., gumminess and chewiness) reduced proportionally as protein concentration decreased as well.

Adhesiveness is the work needed to overcome attractive force between food and other surfaces [30], which, in sensory terms, known as the degree to which the sample sticks to your teeth as mastication progresses [31]. Higher adhesiveness value reported herein for P4 cheese was in accordance to results reported previously by Zheng et al. (2016) who reported that adhesiveness values correlated negatively with protein content [26]. The lower protein content allowed cheeses to melt better and thus increase the adhesiveness. However, excessively high adhesiveness values would cause the problems of cheese package sticking [32].

Protein reduction from 12 to $8 \%$ did not correlate with significant changes in values for springiness. Unexpectedly, cheese with the least protein content (P4 cheese) exhibited the highest springiness value. This was on contradiction with results reported by Zheng et al. (2016) who indicated that reduction in protein content of processed cheese correlated with significant reduction in cheese springiness [26].

Table 2: Textural attributes*1 ${ }^{1}$ of spreadable processed cheeses made with different levels of protein. Data are presented as the means \pm standard deviations.

\begin{tabular}{lllllll}
\hline $\begin{array}{l}\text { Cheese } \\
\text { Codes }^{* 2}\end{array}$ & $\begin{array}{l}\text { Hardness } \\
(\mathrm{g})\end{array}$ & $\begin{array}{l}\text { Adhesiveness } \\
(\mathrm{g} / \mathrm{mm})\end{array}$ & Cohesiveness & $\begin{array}{l}\text { Springiness } \\
(\mathrm{mm})\end{array}$ & $\begin{array}{l}\text { Gumminess } \\
(\mathrm{g})\end{array}$ & $\begin{array}{l}\text { Chewiness } \\
(\mathrm{g})\end{array}$ \\
\hline P1 & $309 \pm 25^{\mathrm{a}}$ & $34.11 \pm 2.10^{\mathrm{b}}$ & $0.70 \pm 0.01^{\mathrm{a}}$ & $3.21 \pm 0.20^{\mathrm{b}}$ & $216 \pm 32.0^{\mathrm{a}}$ & $684.2 \pm 51.5^{\mathrm{a}}$ \\
P2 & $236 \pm 30^{\mathrm{b}}$ & $33.10 \pm 1.90^{\mathrm{b}, \mathrm{c}}$ & $0.70 \pm 0.04^{\mathrm{a}}$ & $3.27 \pm 0.15^{\mathrm{b}}$ & $165 \pm 12.0^{\mathrm{b}}$ & $540.2 \pm 62.0^{\mathrm{b}}$ \\
P3 & $201 \pm 22^{\mathrm{c}}$ & $32.26 \pm 1.85^{\mathrm{c}}$ & $0.68 \pm 0.03^{\mathrm{a}}$ & $3.19 \pm 0.25^{\mathrm{b}}$ & $137 \pm 8.0^{\mathrm{c}}$ & $436.01 \pm 43.0^{\mathrm{c}}$ \\
P4 & $49 \pm 5^{\mathrm{d}}$ & $76.39 \pm 4.20^{\mathrm{a}}$ & $0.59 \pm 0.01^{\mathrm{b}}$ & $4.38 \pm 0.52^{\mathrm{a}}$ & $29 \pm 2.0^{\mathrm{d}}$ & $127.16 \pm 15.2^{\mathrm{d}}$ \\
\hline
\end{tabular}

${ }^{*}$ Analysis was performed after $24 \mathrm{~h}$ of cheese production.

${ }^{* 2} \mathrm{P} 1, \mathrm{P} 2, \mathrm{P} 3$ and P4: cheeses containing $12,10,8$ and $6 \%$ protein, respectively.

Superscript letters following numbers in the same column denote significant differences $(P \leq 0.05)$. 
Effect of stabilizers on chemical and textural attributes of spreadable processed cheeses containing 6\% protein:

Chemical composition and $\mathrm{pH}$ :

The type of added texture stabilizing agents (native starch, modified starch, carrageenan, guar gum, carboxymethyl cellulose, xanthan gum, Hitex 555 and Dairy gel 161) had very little impact on the gross chemical composition and $\mathrm{pH}$ of experimental cheeses. In general, cheeses made with different stabilizers had the following composition: dry matter content (53.0 to 53.7\%), fat (23.5\%), protein (6.00-6.15\%) and salt (0.90-1.10\%). The $\mathrm{pH}$ of different cheeses ranged from 5.68 to 5.73. All cheeses had fat/dry matter ratio ranged from 43.8 to 44.3 which satisfied the Egyptian standards for spreadable processed cheese analogue [14].

\section{Textural attributes:}

Six texture stabilizing agents (including starch, native starch, carrageenan, guar gum, carboxymethyl cellulose, xanthan gum) and two commercial food stabilizers Hitex 555 and Dairy gel 161 were tested for their ability to improve texture of spreadable processed cheese analogue. To better understand the impact of each texture stabilizing agent on rheological behaviour of processed cheese it was necessary to evaluate this impact in low-protein containing cheese. Thereby, the efficiency of such texture stabilizing agent to support texture of low-protein containing processed cheese (6\%) was tested individually and compared to that produced by some commercial food stabilizers (Hitex 555 and Dairy gel 161) (Table 3).

Cheeses containing carrageenan (S3) or commercial stabilizer Hitex 555 (S7) had the least hardness values while cheese made with carboxymethyl cellulose (S5) showed the highest values compared with the remaining cheeses. The effect of different stabilizers on values for hardness was in the following order, carboxymethyl cellulose > xanthan and native starch > Dairy gel $161>$ modified starch > guar gum > Hitex 555 and carrageenan, respectively. The different impact of native and modified starch on cheese hardness may attribute to the differences in their composition mainly amylose/amylopectin ratios. Processed cheeses containing high amylose starch had five-fold increase in firmness, whereas those contained amylopectin based starches yielded only two-fold increase [33].

Adhesiveness values differed significantly among experimental cheeses. Cheeses containing commercial stabilizers Hitex 555 (S7) and Dairy gel 161 (S8) and that with added carboxymethyl cellulose (S5) had significantly $(P \leq 0.05)$ high adhesiveness values compared with the remaining cheeses. However, cheeses containing carrageenan and guar gum had significantly $(P \leq 0.05)$ low adhesiveness values. The effect of different stabilizing agent on adhesiveness values of experimental spreadable cheeses was in the following order, Dairy gel $161>$ carboxymethyl cellulose > Hitex $555>$ xanthan gum > native starch > modified starch > guar gum > carrageenan, respectively.

Cohesiveness values appeared to be significantly $(P \leq 0.05)$ affected by the type of texture stabilizing agent added to spreadable processed cheese analogue. Cheeses containing gums (carrageenan, guar gum and xanthan gum) or carboxymethyl cellulose had significantly $(P \leq 0.05)$ high cohesiveness values. However, cheeses containing native starch and modified starch exhibited the least values. Similarly, previous study showed that the application of native starches in imitated cheese caused significant reduction in values of cohesiveness of the resultant cheese in comparison with starch free cheese [34]. This phenomenon was attributed to the disruption of cheese matrix by swollen starch granules. The order of cohesiveness values generated by different texture stabilizing agents was as follows: carrageenan > carboxymethyl cellulose > guar gum > xanthan gum > Hitex 555> native starch > Dairy gel 161> modified starch, respectively.

Cheeses-containing gums such as carrageenan (S3), guar gum (S4) and xanthan gum (S6) or carboxymethyl cellulose (S5) had higher values $(P \leq 0.05)$ for springiness compared with the remaining cheeses. Similar results was reported for cheeses containing carrageenan and xanthan gums which were usually used to reduce the total solids content in cheese for cutting the cost and to maintain the springiness of the final cheese [26]. In general, values for springiness in different cheeses were in the order of cheese made with carboxymethyl cellulose > guar gum > carrageenan > xanthan gum > Dairy gel $161>$ Hitex $555>$ modified starch > native starch, respectively.

Cheese gumminess, a derived textural parameter, is the product of hardness and cohesiveness [35]. Cheese-containing carboxymethyl cellulose (S5) had the highest gumminess values $(P \leq 0.05)$ followed by xanthan cheese (S6) while cheese made with the commercial stabilizer Hitex 555(S7) had the least values. Cheese gumminess has been shown to correlate positively with the level of added carboxymethyl cellulose and xanthan gum to cream cheese [36]. The order of gumminess values for experimental cheeses was in the order carboxymethyl cellulose $>$ xanthan > native starch $>$ Dairy gel 161 stabilizer $>$ carrageenan $>$ guar gum $>$ modified starch > Hitex 555, respectively.

Values for chewiness depended to far ejxtent on springiness and gumminess values. Chewiness is a derived textural parameter which can be calculated by the following equation: chewiness= gumminess x springiness [20]. Similarly to springiness, cheeses containing carrageenan (S3), guar gum (S4), carboxymethyl cellulose (S5) and xanthan gum (S6) had high chewiness values $(P \leq 0.05)$ compared with cheeses made with native starch $(\mathrm{S} 1)$ and modified starch $(\mathrm{S} 2)$ which had the least values. The effect of different stabilizers on chewiness values were in the order, carboxymethyl cellulose > xanthan > carrageenan > guar gum > Dairy gel $161>$ Hitex $555>$ native starch > modified starch, respectively.

Table 3: Textural attributes ${ }^{1}$ of spreadable processed cheeses made containing $6 \%$ protein. Data are presented as the means \pm standard deviations.

\begin{tabular}{lllllll}
$\begin{array}{l}\text { Cheese } \\
\text { Codes }^{* 2}\end{array}$ & $\begin{array}{l}\text { Hardness } \\
(\mathrm{g})\end{array}$ & $\begin{array}{l}\text { Adhesiveness } \\
(\mathrm{g} / \mathrm{mm})\end{array}$ & Cohesiveness & $\begin{array}{l}\text { Springiness } \\
(\mathrm{mm})\end{array}$ & $\begin{array}{l}\text { Gumminess } \\
(\mathrm{g})\end{array}$ & $\begin{array}{l}\text { Chewiness } \\
(\mathrm{g})\end{array}$ \\
\hline S1 & $141 \pm 12.0^{\mathrm{b}}$ & $73.69 \pm 11.20^{\mathrm{c}}$ & $0.57 \pm 0.03^{\mathrm{e}}$ & $1.06 \pm 0.12^{\mathrm{d}}$ & $80.4 \pm 4.60^{\mathrm{c}}$ & $85.36 \pm 9.10^{\mathrm{g}}$ \\
S2 & $125 \pm 8.00^{\mathrm{c}}$ & $70.16 \pm 2.20^{\mathrm{c}, \mathrm{d}}$ & $0.46 \pm 0.01^{\mathrm{f}}$ & $1.29 \pm 0.07^{\mathrm{d}}$ & $57.5 \pm 3.5^{\mathrm{e}}$ & $74.30 \pm 9.50^{\mathrm{g}}$ \\
S3 & $76 \pm 4.30^{\mathrm{e}}$ & $59.12 \pm 6.10^{\mathrm{e}}$ & $0.94 \pm 0.04^{\mathrm{a}}$ & $13.65 \pm 0.98^{\mathrm{b}}$ & $71.0 \pm 5.50^{\mathrm{c}, \mathrm{d}}$ & $975.06 \pm 121.00^{\mathrm{c}}$ \\
S4 & $91 \pm 8.90^{\mathrm{d}}$ & $62.32 \pm 4.50^{\mathrm{d}, \mathrm{e}}$ & $0.74 \pm 0.09^{\mathrm{c}}$ & $13.82 \pm 1.89^{\mathrm{b}}$ & $67.4 \pm 7.20^{\mathrm{d}}$ & $930.60 \pm 190.00^{\mathrm{d}}$ \\
S5 & $167 \pm 22.00^{\mathrm{a}}$ & $91.32 \pm 11.00^{\mathrm{b}}$ & $0.80 \pm 0.12^{\mathrm{b}}$ & $14.88 \pm 2.12^{\mathrm{a}}$ & $135 \pm 10.15^{\mathrm{a}}$ & $2001.98 \pm 223.00^{\mathrm{a}}$ \\
S6 & $141 \pm 7.20^{\mathrm{b}}$ & $74.51 \pm 5.90^{\mathrm{c}}$ & $0.66 \pm 0.07^{\mathrm{d}}$ & $13.60 \pm 1.98^{\mathrm{b}}$ & $92 \pm 11.00^{\mathrm{b}}$ & $1256.59 \pm 167.07^{\mathrm{b}}$ \\
S7 & $76 \pm 8.50^{\mathrm{c}}$ & $81.08 \pm 7.60^{\mathrm{b}, \mathrm{c}}$ & $0.62 \pm 0.10^{\mathrm{d}}$ & $5.63 \pm 1.05^{\mathrm{c}}$ & $47 \pm 2.23^{\mathrm{e}}$ & $267.07 \pm 35.00^{\mathrm{f}}$ \\
S8 & $137 \pm 20^{\mathrm{b}, \mathrm{c}}$ & $119.21 \pm 19.20^{\mathrm{a}}$ & $0.55 \pm 0.07^{\mathrm{e}}$ & $5.87 \pm 0.75^{\mathrm{c}}$ & $76 \pm 4.11^{\mathrm{c}}$ & $444.29 \pm 67.09^{\mathrm{e}}$ \\
\hline
\end{tabular}

${ }^{n}$ Analysis was performed after $24 \mathrm{~h}$ of cheese production.

${ }^{* 2}$ Cheeses made with different stabilizers including native starch (S1), modified starch (S2), carrageenan (S3), guar gum (S4), carboxymethyl cellulose (S5), xanthan gum (S6), Hitex 555 (S7) and Dairy gel 161 (S8), respectively.

Superscript letters following numbers in the same column denote significant differences $(P \leq 0.05)$.

Based on textural profile generated individually by different textrural stabilizing agents, two stabilizer mixtures were developed and were further used in the manufacture of spreadable cheese. The developed stabilizer mixtures were composed of native starch: modified starch: carrageenan or xanthan at ratio of 85.7 10.7: 3.6 and coded as Car and Xan, respectively.

During the formulation of such stabilizer mixture, it has been taken into consideration that the resultant spreadable cheese should have

1- Acceptable values for hardness, cohesiveness and springiness and potential ability to bind water and emulsion to avoid phase separation. Thereby, native and modified starches were selected to achieve these tasks and they account for $96.4 \%$ of the composition of the developed stabilizer mixtures.

2- An appropriate viscosity/thickening and better mouthfeel. Thus it was necessary to add gum to each stabilizer mixture. Consequently, carrageenan and xanthan gums were added separately to native and modified starches mixture and each gum accounted for 3.6 of total composition of the developed stabilizer mixtures.

Effect of stabilizer mixtures on overall quality of spreadable processed cheese:

Chemical composition and $p H$ :

Table 4 shows the changes in chemical composition and $\mathrm{pH}$ of P1, Car and Xan cheeses during 6 months of storage at ambient temperature. Results indicated that the incorporation of Car or Xan stabilizer mixture into spreadable cheese blends did not drastically affect chemical composition and pH of spreadable cheese throughout storage period. Cheeses showed little variations in dry matter (52.8-53.7\%), fat (23.0-23.5\%) and salt (1.00-1.24\%) content and fat/dry matter ratio (42.8-44.5\%). Changes in pH 
Citation: Nassra Dabour and Ali EL-Shanshory, 2018. The Influence of Protein Content and Some Hydrocolloids on Textural Attributes of Spreadable Processed Cheese. Journal of Applied Sciences Research., 14(5): 5-11. DOI: 10.22587/jasr.2018.14.5.2

were also very limited and all cheeses had $\mathrm{pH}$ range from 5.55 to 5.68. The protein content of P1 was in the range 11.70-11.80\% and 5.95-6.15\% for Car and Xan cheeses. The gross composition data indicated that P1, Car and Xan cheeses satisfied the Egyptian standard specifications for spreadable processed cheese analogue which stipulated that spreadable cheese should contain $35-65 \%$ fat/dry matter and at least $36 \%$ dry matter [14].

Table 4: Changes in gross chemical composition and $\mathrm{pH}$ during storage of spreadable processed cheeses ${ }^{* 1}$ made with developed stabilizer mixture. Data are the means \pm standard deviations.

\begin{tabular}{|c|c|c|c|c|c|c|c|}
\hline $\begin{array}{l}\text { Cheese } \\
\text { code }^{* 2}\end{array}$ & $\begin{array}{l}\text { Cheese age } \\
\text { (month) }\end{array}$ & $\begin{array}{l}\text { Dry matter } \\
(\%)\end{array}$ & $\begin{array}{l}\text { Fat } \\
(\%)\end{array}$ & Fat/dry matter & $\begin{array}{l}\text { Protein } \\
(\%)\end{array}$ & $\begin{array}{l}\text { Salt } \\
(\%)\end{array}$ & $\mathrm{pH}$ \\
\hline \multirow[t]{4}{*}{ P1 } & 0 & $53.70 \pm 0.30^{\mathrm{a}}$ & $23.00 \pm 0.2^{\mathrm{a}}$ & $42.8 \pm 0.23^{\mathrm{c}}$ & $11.75 \pm 0.20^{\mathrm{a}}$ & $1.20 \pm 0.10^{\mathrm{a}}$ & $5.67 \pm 0.03^{\mathrm{a}}$ \\
\hline & 2 & $53.50 \pm 0.20^{\mathrm{a}}$ & $23.00 \pm 0.2^{\mathrm{a}}$ & $43.9 \pm 0.11^{\mathrm{b}}$ & $11.70 \pm 0.20^{\mathrm{a}}$ & $1.22 \pm 0.07^{\mathrm{a}}$ & $5.62 \pm 0.02^{\mathrm{b}}$ \\
\hline & 4 & $53.37 \pm 0.15^{\mathrm{a}}$ & $23.00 \pm 0.1^{\mathrm{a}}$ & $43.1 \pm 0.22^{\mathrm{c}}$ & $11.75 \pm 0.10^{\mathrm{a}}$ & $1.23 \pm 0.11^{\mathrm{a}}$ & $5.57 \pm 0.04^{\mathrm{c}}$ \\
\hline & 6 & $53.35 \pm 0.13^{\mathrm{a}}$ & $23.50 \pm 0.0^{\mathrm{a}}$ & $44.0 \pm 0.00^{\mathrm{b}}$ & $11.80 \pm 0.30^{\mathrm{a}}$ & $1.24 \pm 0.13^{\mathrm{a}}$ & $5.55 \pm 0.02^{\mathrm{c}}$ \\
\hline \multirow[t]{4}{*}{ Car } & 0 & $53.50 \pm 0.40^{\mathrm{a}}$ & $23.00 \pm 0.2^{\mathrm{a}}$ & $43.0 \pm 0.18^{c}$ & $5.95 \pm 0.15^{\mathrm{b}}$ & $1.00 \pm 0.05^{\mathrm{c}}$ & $5.67 \pm 0.05^{\mathrm{a}}$ \\
\hline & 2 & $53.37 \pm 0.44^{\mathrm{a}}$ & $23.00 \pm 0.1^{\mathrm{a}}$ & $43.1 \pm 0.25^{\mathrm{c}}$ & $5.95 \pm 0.00^{\mathrm{b}}$ & $1.02 \pm 0.10^{\mathrm{c}}$ & $5.66 \pm 0.04^{\mathrm{a}}$ \\
\hline & 4 & $53.28 \pm 0.38^{\mathrm{a}, \mathrm{b}}$ & $23.00 \pm 0.3^{\mathrm{a}}$ & $43.1 \pm 0.22^{\mathrm{c}}$ & $6.00 \pm 0.23^{\mathrm{b}}$ & $1.04 \pm 0.10^{\mathrm{b}, \mathrm{c}}$ & $5.61 \pm 0.04^{b}$ \\
\hline & 6 & $53.45 \pm 0.55^{\mathrm{a}}$ & $23.50 \pm 0.3^{\mathrm{a}}$ & $44.0 \pm 0.18^{\mathrm{b}}$ & $6.00 \pm 0.30^{\mathrm{b}}$ & $1.03 \pm 0.17^{\mathrm{c}}$ & $5.60 \pm 0.04^{\mathrm{b}, \mathrm{c}}$ \\
\hline \multirow[t]{4}{*}{ Xan } & 0 & $53.10 \pm 0.45^{\mathrm{b}}$ & $23.50 \pm 0.2^{\mathrm{a}}$ & $44.3 \pm 0.30^{\mathrm{a}, \mathrm{b}}$ & $6.00 \pm 0.29^{b}$ & $1.05 \pm 0.15^{\mathrm{b}}$ & $5.68 \pm 0.00^{\mathrm{a}}$ \\
\hline & 2 & $53.00 \pm 0.50^{\mathrm{b}}$ & $23.50 \pm 0.0^{\mathrm{a}}$ & $44.3 \pm 0.20^{\mathrm{a}}$ & $6.05 \pm 0.34^{\mathrm{b}}$ & $1.07 \pm 0.20^{\mathrm{b}}$ & $5.61 \pm 0.00^{\mathrm{b}}$ \\
\hline & 4 & $52.80 \pm 0.35^{\mathrm{b}}$ & $23.50 \pm 0.3^{\mathrm{a}}$ & $44.5 \pm 0.00^{\mathrm{a}}$ & $6.15 \pm 0.22^{\mathrm{b}}$ & $1.08 \pm 0.20^{\mathrm{b}}$ & $5.58 \pm 0.02^{\mathrm{c}}$ \\
\hline & 6 & $53.00 \pm 0.50^{\mathrm{b}}$ & $23.50 \pm 0.0^{\mathrm{a}}$ & $44.3 \pm 0.00^{\mathrm{a}}$ & $6.10 \pm 0.29^{\mathrm{b}}$ & $1.05 \pm 0.15^{\mathrm{b}}$ & $5.56 \pm 0.03^{\mathrm{c}}$ \\
\hline
\end{tabular}

${ }^{*}$ Cheeses were formulated to contain $6 \%$ protein.

${ }^{* 2}$ P1: cheese made without stabilizers, Car: cheese made with stabilizer mixture composed of native starch: modified starch and carrageenan (85.7, 10.7 and 3.6, respectively), Xan: cheese made with stabilizer mixture composed of native starch: modified starch and xanthan gum (85.7, 10.7 and 3.6, respectively).

Superscript letters following numbers in the same column denote significant differences $(P \leq 0.05)$.

\section{Microbiological quality:}

To evaluate the microbial quality of different experimental cheeses, the viable counts of four microbial groups namely total bacteria, spore-forming (either aerobic or anaerobic), coliform and moulds and yeasts were determined at 2 month interval during 6 months of storage at room temperature. Results revealed that no aerobic- and anaerobic-spore formers, coliform and moulds and yeasts could be detected during storage of any of cheese trials made in this study. This may indicate the effectiveness of heat treatment $\left(90^{\circ} \mathrm{C} / 4 \mathrm{~min}\right)$ applied during processing of ingredients and good hygienic practice during processing and handling of experimental cheese [37].

On the other hand, the total viable bacterial count increased significantly $(P \leq 0.05)$ in all experimental cheeses as storage period progressed. Initial total viable counts determined in fresh chesses ranged from 200 to $220 \mathrm{cfu} / \mathrm{g}$ and increased to 380-401 cfu/g after 6 months of storage. Despite this significant increase, the total viable counts remained within the acceptable levels reported in previous studies. For the microbiological quality of spreadable processed cheese, the Egyptian standards require only the absence of pathogenic microorganisms. The viable bacterial counts reported for the experimental cheeses made in this study were fall in the range of 60 to $5000 \mathrm{cfu} / \mathrm{g}$ [38] for processed cheese spreads and that of $42-87 \times 10^{2} \mathrm{cfu} / \mathrm{g}$ reported for market processed cheese samples [39]. Recent study reported total viable bacterial counts of 200-500 cfu/g reduced-fat block processed cheeses and 250-1300 cfu/g for fat-substituted cheeses [40].

\section{Textural attributes:}

The changes of textural attributes (hardness, adhesiveness, cohesiveness, springiness, gumminess and chewiness) during storage of spreadable processed cheese analogue made with developed stabilizer mixtures are shown in Table 5. It is obvious that the inclusion of such stabilizer mixture in cheese blends resulted in remarkable modification of textural characteristics of the resultant cheeses. The resulted modification appeared to be dependent on the type of added stabilizer mixture and storage time.

In general, Car and Xan cheeses had significantly lower values for hardness, cohesiveness, springiness, gumminess and chewiness compared with stabilizer-free cheese (P1 cheese). However, adhesiveness values were variable among cheeses and appeared to be strongly affected by the type of gum included in stabilizer mixture as well as stage of storage.

During storage, all cheeses exhibited the same tendency in which values for hardness, cohesiveness, springiness, gumminess and chewiness decreased significantly $(P \leq 0.05)$ as storage period progressed. Similar results have been reported by Aly et al. [40]. Adhesiveness values for P1 and Xan cheeses also appeared to decrease significantly $(P \leq 0.05)$ as storage period progressed. Car cheese had different adhesiveness pattern in which adhesiveness reached its summit at 2 month of storage, decreased at 4 month and remained relatively stable till the end of storage period.

Table 5: Changes in textural attributes during storage of spreadable processed cheeses ${ }^{* 1}$ made with developed stabilizer mixture. Data are the means \pm standard deviations.

\begin{tabular}{|c|c|c|c|c|c|c|c|}
\hline $\begin{array}{l}\text { Cheese } \\
\text { code }^{* 2}\end{array}$ & $\begin{array}{l}\text { Cheese age } \\
\text { (month) }\end{array}$ & $\begin{array}{l}\text { Hardness } \\
(\mathrm{g})\end{array}$ & $\begin{array}{l}\text { Adhesiveness } \\
(\mathrm{g} / \mathrm{mm})\end{array}$ & Cohesiveness & $\begin{array}{l}\text { Springiness } \\
(\mathrm{mm})\end{array}$ & $\begin{array}{l}\text { Gumminess } \\
\text { (g) }\end{array}$ & $\begin{array}{l}\text { Chewiness } \\
(\mathrm{g})\end{array}$ \\
\hline \multirow[t]{4}{*}{ P1 } & 0 & $369 \pm 22^{\mathrm{a}}$ & $34.11 \pm 2.00^{b}$ & $0.70 \pm 0.20^{\mathrm{c}}$ & $3.21 \pm 0.20^{\mathrm{a}}$ & $258.3 \pm 37.77^{\mathrm{a}}$ & $829.2 \pm 111^{a}$ \\
\hline & 2 & $309 \pm 13^{\mathrm{b}}$ & $23.16 \pm 1.99^{\mathrm{d}}$ & $0.74 \pm 0.00^{\mathrm{b}, \mathrm{c}}$ & $2.45 \pm 0.19^{\mathrm{c}, \mathrm{d}}$ & $228.6 \pm 58.98^{b}$ & $560.2 \pm 90^{\mathrm{b}}$ \\
\hline & 4 & $137 \pm 9^{c}$ & $15.47 \pm 2.03^{\mathrm{f}}$ & $0.78 \pm 0.01^{\mathrm{a}, \mathrm{b}}$ & $2.38 \pm 0.05^{\mathrm{d}}$ & $106.86 \pm 20.12^{\mathrm{c}}$ & $254.3 \pm 26^{\mathrm{c}}$ \\
\hline & 6 & $110 \pm 6^{\mathrm{d}}$ & $15.80 \pm 1.90^{\mathrm{f}}$ & $0.80 \pm 0.09^{\mathrm{a}}$ & $2.50 \pm 0.15^{\mathrm{c}}$ & $88.00 \pm 12.21^{\mathrm{d}}$ & $220.0 \pm 19^{\mathrm{d}}$ \\
\hline \multirow[t]{4}{*}{ Car } & 0 & $137 \pm 20^{\mathrm{c}}$ & $24.41 \pm 3.11^{\mathrm{d}}$ & $0.69 \pm 0.02^{\mathrm{c}}$ & $2.96 \pm 0.30^{\mathrm{b}}$ & $94.5 \pm 9.44^{\mathrm{d}}$ & $279.88 \pm 35^{\mathrm{c}}$ \\
\hline & 2 & $103 \pm 11^{\mathrm{d}}$ & $40.86 \pm 5.12^{\mathrm{a}}$ & $0.66 \pm 0.10^{\mathrm{d}}$ & $2.40 \pm 0.21^{\mathrm{d}}$ & $68.00 \pm 14.00^{\mathrm{e}}$ & $163.15 \pm 12^{\mathrm{e}}$ \\
\hline & 4 & $87 \pm 14^{\mathrm{e}}$ & $29.32 \pm 2.89^{c}$ & $0.63 \pm 0.09^{\mathrm{d}}$ & $1.75 \pm 0.11^{\mathrm{f}}$ & $54.81 \pm 11.01^{\text {ef }}$ & $95.91 \pm 9^{\mathrm{g}}$ \\
\hline & 6 & $72 \pm 5^{\mathrm{f}}$ & $30.48 \pm 4.15^{\mathrm{c}}$ & $0.52 \pm 0.08^{\mathrm{f}}$ & $1.49 \pm 0.09^{\mathrm{g}}$ & $37.44 \pm 7.13 \mathrm{~g}$ & $55.78 \pm 4^{\mathrm{i}}$ \\
\hline \multirow[t]{4}{*}{ Xan } & 0 & $118 \pm 15^{\mathrm{d}}$ & $36.89 \pm 4.19^{b}$ & $0.68 \pm 0.11^{\mathrm{c}, \mathrm{d}}$ & $2.57 \pm 0.07^{\mathrm{c}}$ & $80.24 \pm 12.01^{\mathrm{d}}$ & $206.21 \pm 13^{\mathrm{d}}$ \\
\hline & 2 & $114 \pm 9^{d}$ & $21.93 \pm 3.77^{\mathrm{d}}$ & $0.59 \pm 0.09^{\mathrm{e}}$ & $2.43 \pm 0.06^{\mathrm{c}, \mathrm{d}}$ & $67.26 \pm 8.12^{\mathrm{e}}$ & $163.44 \pm 6^{\mathrm{e}}$ \\
\hline & 4 & $110 \pm 4^{\mathrm{d}}$ & $21.09 \pm 2.35^{\mathrm{d}}$ & $0.56 \pm 0.11^{\mathrm{e}, \mathrm{f}}$ & $1.9 \pm 0.10^{\mathrm{e}}$ & $61.60 \pm 7.35^{\mathrm{e}}$ & $117.00 \pm 12^{\mathrm{f}}$ \\
\hline & 6 & $95 \pm 3^{\mathrm{e}}$ & $17.97 \pm 2.56^{\mathrm{e}}$ & $0.51 \pm 0.13^{\mathrm{f}}$ & $1.58 \pm 0.20^{\mathrm{g}}$ & $48.45 \pm 6.19^{\mathrm{f}, \mathrm{g}}$ & $76.55 \pm 10^{\mathrm{h}}$ \\
\hline
\end{tabular}

${ }^{*}$ Cheeses were formulated to contain $6 \%$ protein.

${ }^{* 2}$ P1: cheese made without stabilizers, Car: cheese made with stabilizer mixture composed of native starch: modified starch and carrageenan (85.7, 10.7 and 3.6, respectively), Xan: cheese made with stabilizer mixture composed of native starch: modified starch and xanthan gum (85.7, 10.7 and 3.6, respectively).

Superscript letters following numbers in the same column denote significant differences $(P \leq 0.05)$.

\section{Sensorial attributes:}

The effect of Car and Xan stabilizer mixtures on sensorial characteristics (consistency, taste, oiling off, odour, colour and overall acceptability) of spreadable processed cheese analogue is shown in Table 6. Car and Xan cheeses had $(P \leq 0.05)$ higher score for consistency compared with P1 cheese. This effect was remarkable throughout storage period. Fresh control cheese had the highest taste and odour scores $(P \leq 0.05)$ compared with Car and Xan cheeses. All cheeses 
Citation: Nassra Dabour and Ali EL-Shanshory, 2018. The Influence of Protein Content and Some Hydrocolloids on Textural Attributes of Spreadable Processed Cheese. Journal of Applied Sciences Research., 14(5): 5-11. DOI: 10.22587/jasr.2018.14.5.2

showed the same pattern in which taste and odour scores decreased as storage period progressed. The deterioration of taste and odour was much faster in control cheese than Car and Xan cheeses as both cheeses had significantly higher taste and odour scores since the fourth month of storage. The changes of the sensorial scores of oiling off and colour during storage were quite similar to those reported for sensorial taste and odour. In term of overall acceptability, Car and Xan cheeses appeared to be $(P \leq 0.05)$ more acceptable than control P1 cheese.

Table 6: Changes in sensorial attributes during storage of spreadable processed cheeses ${ }^{* 1}$ made with developed stabilizer mixture. Data are the means \pm standard deviations.

\begin{tabular}{|c|c|c|c|c|c|c|c|}
\hline $\begin{array}{l}\text { Cheese } \\
\text { code }^{* 2}\end{array}$ & $\begin{array}{l}\text { Cheese age } \\
\text { (month) }\end{array}$ & $\begin{array}{l}\text { Consistency } \\
(10.0)\end{array}$ & $\begin{array}{l}\text { Taste } \\
(10.0)\end{array}$ & $\begin{array}{l}\text { Oiling off } \\
(10.0)\end{array}$ & $\begin{array}{l}\text { Odour } \\
(10.0)\end{array}$ & $\begin{array}{l}\text { Colour } \\
(10.0)\end{array}$ & $\begin{array}{l}\text { Overall } \\
\text { acceptability } \\
(50.0)\end{array}$ \\
\hline \multirow[t]{4}{*}{ P1 } & 0 & $8.00 \pm 1.20^{\mathrm{c}}$ & $8.60 \pm 0.80^{\mathrm{a}}$ & $9.00 \pm 1.50^{\mathrm{a}}$ & $8.30 \pm 0.60^{\mathrm{a}}$ & $9.00 \pm 1.00^{\mathrm{a}}$ & $42.90 \pm 3.60^{\mathrm{a}}$ \\
\hline & 2 & $7.00 \pm 0.90^{\mathrm{d}}$ & $8.30 \pm 1.30^{\mathrm{a}, \mathrm{b}}$ & $9.00 \pm 1.50^{\mathrm{a}}$ & $8.00 \pm 0.90^{\mathrm{a}}$ & $8.50 \pm 1.20^{\mathrm{b}}$ & $40.80 \pm 2.40^{\mathrm{e}}$ \\
\hline & 4 & $7.00 \pm 0.65^{\mathrm{d}}$ & $7.70 \pm 0.35^{\mathrm{c}, \mathrm{d}}$ & $8.00 \pm 1.02^{\mathrm{c}}$ & $8.00 \pm 0.98^{\mathrm{a}}$ & $7.80 \pm 0.70^{c}$ & $38.50 \pm 2.00^{f}$ \\
\hline & 6 & $7.00 \pm 1.00^{\mathrm{d}}$ & $6.50 \pm 1.10^{\mathrm{e}}$ & $8.00 \pm 0.80^{c}$ & $7.50 \pm 1.20^{\mathrm{b}}$ & $7.00 \pm 1.00^{\mathrm{d}}$ & $36.00 \pm 2.60^{\mathrm{g}}$ \\
\hline \multirow[t]{4}{*}{ Car } & 0 & $8.50 \pm 0.40^{b}$ & $8.00 \pm 0.60^{b, c}$ & $9.00 \pm 1.20^{\mathrm{a}}$ & $8.00 \pm 1.00^{\mathrm{a}}$ & $9.00 \pm 1.20^{\mathrm{a}}$ & $42.50 \pm 3.00^{\mathrm{a}, \mathrm{b}}$ \\
\hline & 2 & $8.00 \pm 1.00^{\mathrm{c}}$ & $8.00 \pm 0.80^{b, c}$ & $9.00 \pm 1.60^{\mathrm{a}}$ & $8.00 \pm 1.20^{\mathrm{a}}$ & $9.00 \pm 1.50^{\mathrm{a}}$ & $42.00 \pm 4.10^{\mathrm{c}, \mathrm{d}}$ \\
\hline & 4 & $8.80 \pm 1.20^{\mathrm{a}, \mathrm{b}}$ & $7.80 \pm 1.25^{\mathrm{c}, \mathrm{d}}$ & $8.50 \pm 1.60^{b}$ & $8.00 \pm 1.40^{\mathrm{a}}$ & $8.50 \pm 0.80^{b}$ & $41.60 \pm 3.02^{\mathrm{d}}$ \\
\hline & 6 & $8.00 \pm 0.90^{\mathrm{c}}$ & $7.50 \pm 1.40^{\mathrm{d}}$ & $8.00 \pm 1.30^{c}$ & $8.00 \pm 1.10^{\mathrm{a}}$ & $8.50 \pm 0.90^{\mathrm{b}}$ & $40.00 \pm 2.90^{\mathrm{e}}$ \\
\hline \multirow[t]{4}{*}{ Xan } & 0 & $8.80 \pm 0.60^{\mathrm{a}, \mathrm{b}}$ & $8.00 \pm 0.50^{\mathrm{b}, \mathrm{c}}$ & $9.10 \pm 0.40^{\mathrm{a}}$ & $8.00 \pm 1.20^{\mathrm{a}}$ & $8.80 \pm 1.30^{\mathrm{a}, \mathrm{b}}$ & $42.70 \pm 2.80^{\mathrm{a}}$ \\
\hline & 2 & $9.00 \pm 1.60^{\mathrm{a}}$ & $8.00 \pm 1.20^{\mathrm{b}, \mathrm{c}}$ & $9.00 \pm 1.50^{\mathrm{a}}$ & $8.00 \pm 0.90^{\mathrm{a}}$ & $8.40 \pm 1.00^{\mathrm{b}}$ & $42.40 \pm 3.90^{\mathrm{b}, \mathrm{c}}$ \\
\hline & 4 & $9.00 \pm 1.90^{\mathrm{a}}$ & $8.00 \pm 1.70^{b, c}$ & $9.00 \pm 1.50^{\mathrm{a}}$ & $8.00 \pm 1.80^{\mathrm{a}}$ & $8.50 \pm 1.68^{b}$ & $42.50 \pm 3.20^{\mathrm{b}}$ \\
\hline & 6 & $8.50 \pm 1.50^{b}$ & $7.70 \pm 1.60^{\mathrm{c}, \mathrm{d}}$ & $8.00 \pm 1.10^{\mathrm{c}}$ & $8.00 \pm 1.00^{\mathrm{a}}$ & $8.50 \pm 1.30^{\mathrm{b}}$ & $40.70 \pm 2.80^{\mathrm{e}}$ \\
\hline
\end{tabular}

${ }^{* 1}$ Cheeses were formulated to contain $6 \%$ protein.

${ }^{* 2}$ P1: cheese made without stabilizers, Car: cheese made with stabilizer mixture composed of native starch: modified starch and carrageenan (85.7, 10.7 and 3.6, respectively), Xan: cheese made with stabilizer mixture composed of native starch: modified starch and xanthan gum (85.7, 10.7 and 3.6, respectively).

Superscript letters following numbers in the same column denote significant differences $(P \leq 0.05)$.

\section{Conclusion:}

Results reported in this study indicated that protein concentration and type of added texture stabilizing agent had both significant impact on textural attributes of spreadable processed cheese analogue. Using cheese model with low protein concentration to evaluate the efficiency of individual stabilizers to improve textural properties of spreadable cheese indicated that the production of cheese with appropriate textural attributes did not depend on the application of single stabilizer. As cheese texture is a result of the interaction of many factors and characteristics, the application of stabilizer mixture would be better to improve texture of spreadable cheese rather than use of single stabilizer agent. Thereby, two stabilizer mixtures composed of native starch: modified starch: carrageenan or xanthan at ratio of 85.7: 10.7: 3.6, respectively, were incorporated in spreadable processed cheese blends. Both mixtures had no adverse effects on chemical, microbiological, textural and sensorial attributes of spreadable cheese. Thus, it could be recommended to be used either stabilizer mixture to improve textural characteristics of spreadable cheeses particularly those containing low-protein content.

\section{REFERENCES}

[1] FAO statistics, 2011. http://faostat.fao.org/site/535/default.aspx.

[2] Maurer, A., G. Scheurer, 2012. Processed cheese manufacture and stabilization of dairy products. Eds., Giulini B. K., GmbH, Ludwigshafen, Germany, pp: $1-50$.

[3] Walstra, P., 1990. On the stability of casein micelles. Journal of Dairy Science, 73(9): 1965-1979.

[4] Guinee, T.P., M. Caric, M. Kalab, 2004. Pasteurized processed cheese and substitute/imitation cheese products. In Cheese: chemistry, physics and microbiology. Volume 2: major cheese groups. Eds., Fox P. F., Elsevier Applied Science, London UK, pp: $349-394$.

[5] Lucey, J.A., M. E. Johnson and D.S. Horne, 2003. Perspectives on the basis of the rheology and texture properties of cheese. Journal of Dairy Science, 86(9): $2725-2743$.

[6] Guinee, T.P. and B.T. O'Kennedy, 2012. Reducing the level of added disodium phosphate alters the chemical and physical properties of processed cheese. Dairy Science and Technology, 92(5): 469-486.

[7] Cashman, K.D., 2006. Milk minerals (including trace elements) and bone health. International Dairy Journal, 16(11): 1389-1398.

[8] He, F.J., G.A. McGregor, 2007. In: Kilcast D, Angus F (eds) Reducing salt in foods practical strategies. Woodhead, Cambridge.

[9] Palar, K., R. Sturm, 2009. Potential societal savings from reduced sodium consumption in the US adult population. American Journal of Health Promotion, 24(1): 49-57.

[10] Cerníková, M., F. Bunka, M. Pospiech, B. Tremlová, K. Hladká, V. Pavlínek, P. Brezina, 2010. Replacement of traditional emulsifying salts by selected hydrocolloids in processed cheese production. International Dairy Journal, 20(5): 336-343.

[11] Dickinson, E., 2003. Hydrocolloids at interfaces and the influence on the properties of dispersed systems. Food Hydrocolloids, 17 (1): 25-39.

[12] Tan, Y.L., A. Ye, H. Singh, Y. Hemar, 2007. Effects of biopolymer addition on the dynamic rheology and microstructure of renneted skim milk system. Journal of Texture Studies, 38(3): 404-422.

[13] Kosikowski, F.V., 1982. Processed cheese and related types. In: Fermented Milk Foods. Kosikowski FV (eds), Kosikowski F.V. and associates, P.O. Box 139, Brookdontale, New York. Second edition, pp: 382-406.

[14] Egyptian Standards Organization, 2013. Standard specifications of processed cheese and spreadable processed cheese with vegetable oils and fats. Document No. 11322013.

[15] AOAC, 1995. Official Methods of Analysis. 16th ed. Association of Official Analytical Chemists. Inc. Arlington, Virginia, USA.

[16] International Dairy Federation, 1993. Determination of nitrogen content by Kjeldahl method. Standard B20. International Dairy Federation, Brussels, Belgium.

[17] Palmas, F., S. Cosentino, M.E. Fadda, M. Deplano, M. Mascia, 1999. Microbial characteristics of Pecorino processed Cheese spreads. Lait, 79(8): 607-613.

[18] Harrigan, W.F. and M.E. McCance, 1976. Laboratory Methods in Microbiology, Academic press, London and New York, USA.

[19] Wehr, M., J.F. Frank, 2004. Tests for groups of microorganisms. In: Standard Methods for the Examination of Dairy Products. American Public Health Association, NW, Washington, DC, USA, pp: 242-245.

[20] International Dairy Federation, 1991. Rheological and fracture properties of cheese, IDF Bulletin 268. International Dairy Federation. Brussels, Belgium.

[21] El-Shibiny, S., M.A.M. Abd El-Gawad, F.M. Assem, F.L. Seleet, S.A. Abou Dawood, M. Elaaser, 2013. Preparation, composition and microbiological and rheological properties of functional processed cheese supplemented with rice bran. Journal of Applied Sciences Research, 9(8): 4927-4934.

[22] Steel, R.G. and J.H. Torrie, 1980. Principles and procedures of statistics $2^{\text {nd }}$ ed. McGraw Hill, New York, USA.

[23] Buñka, F., V. Pavlínek, J. Hrabe, O. Rop, R. Janis, J. Krejcí, 2007. Effect of 1-monoglycerides on viscoelastic properties of processed cheese. International Journal of Food Properties, 10(4): 819-828.

[24] Dimitreli, G., A.S. Thomareis, 2007. Texture evaluation of block-type processed cheese as a function of chemical composition and in relation to its apparent viscosity. Journal of Food Engineering, 79(4): 1364-1373. 
Citation: Nassra Dabour and Ali EL-Shanshory, 2018. The Influence of Protein Content and Some Hydrocolloids on Textural Attributes of Spreadable Processed Cheese. Journal of Applied Sciences Research., 14(5): 5-11. DOI: 10.22587/jasr.2018.14.5.2

[25] Shirashoji, N., J.J. Jaeggi, J.A. Lucey, 2006. Effect of trisodium citrate concentration and cooking time on the physicochemical properties of pasteurized process cheese. Journal of Dairy Science, 89(1): 15-28.

[26] Zheng, Y., Z. Liu, B. Mo, 2016. Texture profile analysis of sliced cheese in relation to chemical composition and storage temperature. Journal of chemistry, vol. 2016, Article ID 8690380, 10 pages, 2016. doi:10.1155/2016/8690380

[27] Joshi, N.S., R.P. Jhala, M.R. Acharya, K. Muthukumarappan, V.V. Mistry, 2004. Textural and rheological properties of processed cheese. International Journal of Food Properties, 7(3): 519-530.

[28] Sołowiej, B., I.M.Y. Cheung, E.C.Y. Li-Chan, 2014. Texture, rheology and meltability of processed cheese analogues prepared using rennet or acid casein with or without added whey proteins. International Dairy Journal, 37(8): 87-94.

[29] Lee, K.S., H. Klostermeyer, S.G. Anema, 2015. Effect of fat and protein-in-water concentrations on the properties of model processed cheese. International Dairy Journal, 50(11): 15-23.

[30] Tunick, M.H., 2000. Rheology of dairy foods that gel, stretch, and fracture. Journal of Dairy Science, 83(8): 1892-1898.

[31] Gwartney, E.A., D.K. Larick, E.A. Foegeding, 2004. Sensory texture and mechanical properties of stranded and particulate whey protein emulsion gels. Journal of Food Science, 69(9): S333-S339.

[32] Juan, B., A.J. Trujillo, V. Guamis, M. Buffa, V. Ferragut, 2007. Rheological, textural and sensory characteristics of high-pressure treated semi-hard ewes' milk cheese. International Dairy Journal, 17(3): 248-254.

[33] Gampala, P., C.S. Brennan, 2008. Potential starch utilisation in a model processed cheese system. Starch, 60(12): 685-689.

[34] Mounsey, J.S., E.D. O'Riordan, 2008. Modification of imitation cheese structure and rheology using pre-gelatinised starches. European Food Research and Technology, 226(5): 1039-1046.

[35] Mesbahi, G., M. Niakoosari, S. Savadkoohi, A. Farahnaky, 2010. A comparative study on the functional properties of carboxymethyl cellulose produced from sugar-beet pulp and other thickeners in tomato ketchup. Scientific Information Database, 7(3): 62-73.

[36] Salari, S., M. Zanganeh, A. Fadavi, Z. Ahmadi, 2017. Effect of xanthan gum and carboxymethyl cellulose on physical properties of cream cheese. International Journal of Advanced Technology, 8(176) doi:10.4172/0976-4860.1000176.

[37] Abd Rabou, F.H., A.M. Abd El-Fattah, M.M. El-Sayed, A.G. Mohamed, 2005. Improvement of nutritional value of processed cheese by using emulsifying salts. Egyptian Journal of Dairy Science, 33(2): 85: 103-112.

[38] Mahfouz, M.B., H.F. El-Dein, S. El-Shibiny, H.F. Haggag, M.N. Magdoub, 1986. Chemical and microbiological quality of market processed cheese. Egyptian Journal of Dairy Science, 14(1): 33-41.

[39] Abd Alla, E.A.M., K. El-Shafei, G.A. Ibrahim, O.M. Sharaf, 1996. Changes in microflora and biogenic amines of some market processed cheeses during storage. Egyptian Journal of Dairy Science, 24(3): 217-226.

[40] Aly, E.A., K. EL Saadany, E. El Dakkakny, E.E. Kheadr, 2017. The use of bulgur in the production of reduced-fat and substituted fat block type processed cheeses. Journal of Applied Science Research, 13(1): 17-30. 